\title{
Historical Analysis of Income Statement - A Case Study Salalah Mills Company Oman
}

Balamurugan Muthuraman ${ }^{1}$ and Abdullah Khalfan Salim Al Mawali ${ }^{2}$

Administrative and Financial Sciences, Oman College of Management \& Technology

Sultanate of Oman

Email: ${ }^{1}$ balamurugan.muthuraman@omancollege.edu.om, ${ }^{2}$ 201822007@ omancollege.edu.om

Article History: Received on $19^{\text {th }}$ Nov. 2020, Revised on $16^{\text {th }}$ Dec. 2020, Published on $9^{\text {th }}$ Jan. 2021

\section{Abstract}

Purpose of the study: The objectives of the study were to critically analyse the financial performance of Salalah Mills Company (SMC), to examine the income statement position of the company and to study the profitability position and improvements of Salalah Mills Company.

Design/Methodology/Approach: The secondary data was obtained from the annual reports of Salalah Mills Company through the income statement for the period 2015 to 2019. The collected data was analysed using financial ratios involving excel and SPSS, to evaluate the Salalah Mills Company (SMC) profitability.

Findings: The study revealed that the reducing in company's gross profit (profit margin), pre-tax margin was due to the increase in cost of goods sold, administrative expenses, the cost of materials consumed, the selling and distribution expenses and the labour cost.

Research Implications: The study suggested that the company should reduce the cost of sales and administrative expenses to achieve increased gross profit margin. It was also suggested that the company should focus more towards marketing.

Practical Implications: The study suggested that the company should look for alternative for the raw materials such as buying wheat from the local farmers. It was also suggested that the company should work on finding ways and means to achieve good profits so as to satisfy the shareholders.

Originality/value: This research work is of its first own kind as the study focuses on the accounting perspectives of the food company in the Sultanate of Oman.

Keywords: Direct cost of sales, Operating Income of the Flour Mills, Income Statement Analysis, Financial ratios, Market share of flour mills.

\section{Introduction}

During the financial crisis, businesses are facing different challenges. Businesses need to focus on either economic, social, political, or technological factors. To make it survive from the battling business environment characterized by intense competition, not necessarily to achieve progress and prosperity, but often for the sake of survival. The larger the size of institutions and the complexity, the intertwining activities and work necessitate accurate information that effectively benefits the decision-makers at all levels. Especially, financial information is the one which helps to improve the performance of institutions. Its quality and accuracy if it is not considered at the right time will affect the business directly. In every business, growth is focused on the financial information obtained from the financial statement of the company. Financial information is an important tool which helps to make proper financial decisions by the management. Obtaining accurate information is the basis on which financial statements of various kinds are built. Ratios analysis is one of the methods that allow the institutions to take the right decisions to position in the marketplace among the competition phases. Adopting to this technique, the institution can discover the strength and weakness that help to survive.

\section{Statement of the problem}

The food sector is one of the most important sectors that people care about for sustainability. The importance of milling companies stems from what they provide as basic products that are included in various types of food, especially in Oman. The problem of fluctuating wheat prices is the biggest challenge facing the milling sector, as it cannot establish a fixed price policy for its products. Governments support the milling sector to maintain a constant price for its products so that it is affordable for everyone. Salalah Mills Company (SMC), which was established in 1970, which is producing wheat products and marketing them to all regions of the Sultanate of Oman is facing many challenges due to huge competition from local and foreign companies. SMC is trying to reduce its market share which will make it difficult for the company to achieve the desired profitability of the shareholders and the founders.

So this study explored to analyse the impact of competition on the performance of the company and the steps involved to overcome the impacts. The study highlighted the strengths, opportunities, weaknesses, and 
threats. The main problem of the study was in measuring the financial performance of SMC and the future growth achievement.

\section{Objectives of the study}

The objectives of the study were:

- To critically analyse the financial performance of Salalah Mills Company (SMC)

- To examine the income statement position of the company

- To study the profitability position and improvements of Salalah Mills Company

\section{Review of Literature}

Khoja et al., (2016) revealed that the managers pay less concentration on non-strategic sales to reduce susceptibility to insolvency in the GCC. Bartoloni and Baussola (2014) confirmed that the use of multiple methodological tools to correct the evaluation of firms' creditworthiness and fine-tuning procedures requiring to reach success. Efuntade and Akinola (2020) studied that the production processes lead to an increase in profit with the use of the maximum resources. Harb (2019) claimed that the focus should be on the strength of the firms' operations to improving production efficiency to avoid the impact of profitability. Duarte et al., (2011) confirmed that the effective practices on performance might be context-dependent in the industries. Suardi and Noor (2015) claimed that the total assets are reliable to cover the debt. Capkun et al., (2009) stated that the ratio between inventory and performance is more highly correlated with the operating profit measures. Sahore and Verma (2017) analysed the possible consequences in economic conditions and performance growth of the manufacturing and non-manufacturing companies. Kaplan (1983) found that the short-term financial process is more consistent to compare the long-term effectiveness and profitability. Williams (2020) claimed that U.S. Small Medium Enterprises (SMEs) need to consider financial performance growth to improve their business during the investment period.

Padma and Prabhakaran (2019) used ratio analyses and found growth had a negative value in the Indian food products industry. Yalcin et al. (2012) found that the manufacturing industries' financial positions were at the same level. Gatsi et al. (2013) revealed that the corporate income tax and financial performance are negatively correlated. Kangari et al. (1992) used financial ratios, measured the grade of the construction companies.

Gazzola and Amelio (2014) revealed that the evaluation of financial performance during the investment process is informative content. Behn and Riley (1999) revealed that the expenses and operating income information appears as a non-financial performance. Gamayuni (2015) revealed that the firm value of the public company created significant influences on financial performance. Zahra and Das, (1993) evaluated the innovation strategy towards to the financial performance of the manufacturing companies.

\section{Findings}

Table 1. Operational Analysis Tools

\begin{tabular}{|c|c|c|}
\hline Ratio & Formula & References \\
\hline Gross Profit Maroin Ratio & Gross Profit & \multirow{4}{*}{$\frac{\text { Nariswari and }}{\text { Nugraha. }(2020)}$} \\
\hline Gross Pronl Margm Kato & Revenue & \\
\hline \multirow{2}{*}{ Net Profit Margin Ratio } & Net Income & \\
\hline & Revenue & \\
\hline \multirow{2}{*}{ Operating Margin Ratio } & Operating Income & \multirow{2}{*}{$\frac{\text { Filer and Golbe }}{(2003)}$} \\
\hline & Revenue & \\
\hline \multirow{2}{*}{ Net Profit Ratio } & Net Profit after Tax & \\
\hline & Net Sales & \\
\hline Administrative Expenses to & Administrative Expenses & \\
\hline Sales Ratio & Net Sales & \\
\hline Selling and Distribution & Selling and Distribution Expenses & \\
\hline Expenses to Sales Ratio & Net Sales & \\
\hline \multirow{2}{*}{ Labour cost to Sales Ratio } & Labour Cost & \\
\hline & $\begin{array}{c}\text { Net Sales } \\
\end{array}$ & \\
\hline \multirow{2}{*}{ Interest Coverage Ratio } & Earnings Before Interest \& Taxes & \\
\hline & Interest Expenses & \multirow{7}{*}{ (Khan, 2019) } \\
\hline \multirow{2}{*}{ Cost of Goods sold Ratio } & Cost of Goods Sold & \\
\hline & Net Sales & \\
\hline \multirow{2}{*}{ Pre-tax Profit Margin } & Profit before Tax & \\
\hline & Net Sales & \\
\hline Materials consumed to Sales & Cost of direct materials & \\
\hline Ratio & Sales & \\
\hline
\end{tabular}


Table 2. Gross Profit Margin Ratio

\begin{tabular}{|c|c|c|c|}
\hline Year & $\begin{array}{c}\text { Gross } \\
\text { Profit }\end{array}$ & Revenue & Ratio \\
\hline $\mathbf{2 0 1 5}$ & $9,416,857$ & $68,342,932$ & $13.78 \%$ \\
\hline $\mathbf{2 0 1 6}$ & $8,110,017$ & $57,299,384$ & $14.15 \%$ \\
\hline $\mathbf{2 0 1 7}$ & $8,851,816$ & $57,170,760$ & $15.48 \%$ \\
\hline $\mathbf{2 0 1 8}$ & $7,366,644$ & $52,022,806$ & $14.16 \%$ \\
\hline $\mathbf{2 0 1 9}$ & $4,946,050$ & $53,662,614$ & $9.22 \%$ \\
\hline
\end{tabular}

Table. 2 shows that the company's sales compared to the profit realized after deducting the direct costs were in a slight growth during the first four years, as it achieved $13.78 \%$ in $2015,14.15 \%$ in $2016,15.48 \%$ in 2017 , and $14.16 \%$ in 2018 , while this percentage decreased significantly in 2019 and reached $9.22 \%$.

Table 3. Profit Margin Ratio

\begin{tabular}{|c|c|c|c|}
\hline Year & Net Profit & Revenue & Ratio \\
\hline 2015 & $5,240,842$ & $68,342,932$ & $7.67 \%$ \\
\hline 2016 & $3,519,078$ & $57,299,384$ & $6.14 \%$ \\
\hline 2017 & $3,927,298$ & $57,170,760$ & $6.87 \%$ \\
\hline 2018 & $3,237,526$ & $52,022,806$ & $6.22 \%$ \\
\hline 2019 & $1,582,367$ & $53,662,614$ & $2.95 \%$ \\
\hline
\end{tabular}

Source: Company Annual Reports

According to table.3, it is clear that the profit margin was the highest in 2015 reaching $7.67 \%$, while it got decreased in the following years, in $2016,6.14 \%$, in $2017,6.87 \%$, and in $2018,6.22 \%$, until it reached its lowest in 2019, reaching $2.95 \%$. This is because the net profit decreased in 2019 to RO 1.5 million while it was RO 5.2 million and the revenue decreased in 2019 to R.O. 53.6 million compared to R.O. 68.3 million in 2015 .

Table 4. Operating Margin Ratio

\begin{tabular}{|c|c|c|c|}
\hline Year & $\begin{array}{c}\text { Operating } \\
\text { income }\end{array}$ & Revenue & Ratio \\
\hline 2015 & $5,883,925$ & $68,342,932$ & $8.61 \%$ \\
\hline 2016 & $4,844,379$ & $57,299,384$ & $8.45 \%$ \\
\hline 2017 & $5,455,850$ & $57,170,760$ & $9.54 \%$ \\
\hline 2018 & $4,436,702$ & $52,022,806$ & $8.53 \%$ \\
\hline 2019 & $2,078,437$ & $53,662,614$ & $3.87 \%$ \\
\hline
\end{tabular}

Table. 4 indicates that the company achieved the highest profit margin from operations in 2017 (9.54\%), while in the years 2015,2016 , and 2018 it was relatively close, as it reached $8.16 \%, 8.45 \%$, and $8.53 \%$ respectively. However, in the year 2019 it witnessed a significant decrease as it reached $3.87 \%$.

Table 5. Administrative Expense to Sales Ratio

\begin{tabular}{|c|c|c|c|}
\hline Year & $\begin{array}{c}\text { Administrative } \\
\text { Expenses }\end{array}$ & Net Sales & Ratio \\
\hline 2015 & $3,110,558$ & $68,342,932$ & $4.55 \%$ \\
\hline 2016 & $3,221,646$ & $57,299,384$ & $5.62 \%$ \\
\hline 2017 & $3,354,064$ & $57,170,760$ & $5.87 \%$ \\
\hline 2018 & $3.334,521$ & $52,022,806$ & $6.41 \%$ \\
\hline 2019 & $3,415,994$ & $53,662,614$ & $6.37 \%$ \\
\hline
\end{tabular}

Source: Company Annual Reports 
It appeared from table. 5 that the ratio of sales to administrative expenses of the company was at its highest in 2018 as it reached $6.41 \%$, followed by $6.37 \%$ in 2019, and it reached similar proportions in 2016 and 2017 $5.62 \%$ and $5.87 \%$ respectively, while the lowest percentage was $4.55 \%$ in 2015 .

Table 6. Selling and Distribution Expenses to Sales Ratio

\begin{tabular}{|c|c|c|c|}
\hline Year & $\begin{array}{c}\text { Selling and } \\
\text { Distribution } \\
\text { Expenses }\end{array}$ & Net Sales & Ratio \\
\hline 2015 & 208,973 & $68,342,932$ & $0.31 \%$ \\
\hline 2016 & 240,343 & $57,299,384$ & $0.41 \%$ \\
\hline 2017 & 144,998 & $57,170,760$ & $0.25 \%$ \\
\hline 2018 & 163,301 & $52,022,806$ & $0.31 \%$ \\
\hline 2019 & 125,188 & $53,662,614$ & $0.23 \%$ \\
\hline
\end{tabular}

Source: Company Annual Reports

It is clear from table. 6 that the ratio of selling and distribution expenses to sales recorded the highest $(0.41 \%)$ in 2016, while in 2015 and 2018 it was $0.31 \%$, and in 2017 it scored $0.25 \%$, while 2019 recorded the lowest $(0.23 \%)$.

Table 7. Labour Cost to Sales Ratio

\begin{tabular}{|c|c|c|c|}
\hline Year & Labour Cost & Net Sales & Ratio \\
\hline 2015 & $4,691,299$ & $68,342,932$ & $6.86 \%$ \\
\hline 2016 & $4,620,120$ & $57,299,384$ & $8.06 \%$ \\
\hline 2017 & $4,750,443$ & $57,170,760$ & $8.31 \%$ \\
\hline 2018 & $4,805,676$ & $52,022,806$ & $9.24 \%$ \\
\hline 2019 & $5,271,262$ & $53,662,614$ & $9.82 \%$ \\
\hline
\end{tabular}

Source: Company Annual Reports

Table. 7 shows that the ratio of labour cost to sales was in an annual increase, as it was lowest in $2015(6.86 \%)$, and in 2016, it rose to $8.06 \%$, in $2017-8.31 \%$, and $2018-9.24 \%$, until it reached its highest $-9.82 \%$ in 2019 .

Table 8. Interest Coverage Ratio

\begin{tabular}{|c|c|c|c|}
\hline Year & EBIT & $\begin{array}{c}\text { Interest } \\
\text { Expenses }\end{array}$ & Ratio \\
\hline 2015 & $5,918,176$ & 360,374 & 16.42 \\
\hline 2016 & $4,138,630$ & 676,158 & 6.12 \\
\hline 2017 & $4,732,333$ & 723,517 & 6.54 \\
\hline 2018 & $3,856,170$ & 580,532 & 6.64 \\
\hline 2019 & $1,326,951$ & 751,486 & 1.77 \\
\hline
\end{tabular}

Source: Company Annual Reports

Table. 8 shows that the company had the highest ability to pay interest in 2015 , equivalent to 16.42 times, but this percentage decreased in 2016 to 6.12 times, in 20176.54 times, and in 20186.64 times, until it reached its lowest in 2019 as it reached 1.77 times.

Table 9. Cost of Goods Sold Ratio

\begin{tabular}{|c|c|c|c|}
\hline Year & $\begin{array}{c}\text { Cost of } \\
\text { Goods sold }\end{array}$ & Net Sales & Ratio \\
\hline 2015 & $58,926,075$ & $68,342,932$ & $86.22 \%$ \\
\hline 2016 & $49,189,367$ & $57,299,384$ & $85.85 \%$ \\
\hline 2017 & $48,318,944$ & $57,170,760$ & $84.52 \%$ \\
\hline 2018 & $44,656,162$ & $52,022,806$ & $85.84 \%$ \\
\hline 2019 & $48,716,614$ & $53,662,614$ & $90.78 \%$ \\
\hline
\end{tabular}

Source: Company Annual Reports

Table. 9 shows that the ratio of cost of goods sold to sales was at its highest in 2019 (90.78\%), while its lowest was $84.52 \%$ in 2017, and it recorded close proportions in the years 2015, 2016 and 2018, 86.22\% and 85.85 $\%$ and $85.84 \%$, respectively. 
Table 10. Pre-tax Profit Margin Ratio

\begin{tabular}{|c|c|c|c|}
\hline Year & $\begin{array}{c}\text { Profit } \\
\text { before Tax }\end{array}$ & Net Sales & Ratio \\
\hline 2015 & $5,918,176$ & $68,342,932$ & $8.66 \%$ \\
\hline 2016 & $4,138,630$ & $57,299,384$ & $7.22 \%$ \\
\hline 2017 & $4,732,333$ & $57,170,760$ & $8.28 \%$ \\
\hline 2018 & $3,856,170$ & $52,022,806$ & $7.41 \%$ \\
\hline 2019 & $1,326,951$ & $53,662,614$ & $2.47 \%$ \\
\hline
\end{tabular}

Source: Company Annual Reports

From table.10, it is clear that the pre-tax profit margin ratio was at its high $(8.66 \%)$ in 2015 , followed by $8.28 \%$ in 2017, whereas the company recorded close rates in 2016 and 2018 of $7.22 \%$ and $7.41 \%$, respectively. However, this percentage decreased sharply in 2019, reaching $2.47 \%$.

Table 11. Materials consumed to Sales Ratio

\begin{tabular}{|c|c|c|c|}
\hline Year & $\begin{array}{c}\text { Cost of direct } \\
\text { materials }\end{array}$ & Net Sales & Ratio \\
\hline 2015 & $50,989,089$ & $68,342,932$ & $74.61 \%$ \\
\hline 2016 & $41,648,562$ & $57,299,384$ & $72.68 \%$ \\
\hline 2017 & $39,930,469$ & $57,170,760$ & $69.84 \%$ \\
\hline 2018 & $36,299,783$ & $52,022,806$ & $69.78 \%$ \\
\hline 2019 & $39,895,663$ & $53,662,614$ & $74.35 \%$ \\
\hline
\end{tabular}

Source: Company Annual Reports

Table.11 shows that the year 2018 recorded the lowest ratio of materials consumed to sales $(69.78 \%)$, while the highest rate was $(74.61 \%$ ) in 2015. In 2019, it recorded $74.35 \%$, which is slightly higher compared to the previous years. Overall, the cost of materials consumed to sales increased due to higher wheat prices and losses of the pasta manufacturing sector in 2019.

\section{Observations}

The company's Gross profit were increasing during the first four years, while it decreased significantly in 2019. The company achieved the highest profit margin from operations in 2017. The pre-tax profit margin was high in 2015 and decreased sharply in 2019.

The ratio of cost of goods sold to sales was high in 2019. It appears that the ratio of sales to administrative expenses in the company was at highest in 2018 while it was lowest in 2015. Materials consumed to sales was low in 2018 but the cost of materials consumed to sales has was high due to wheat prices in 2019. The selling and distribution expenses to sales recorded the highest in 2016, while recorded the lowest in 2019. Labour cost to sales was at low in 2015 and was high in 2019. The company had the highest ability to pay interest in 2015 and this percentage kept decreasing from 2016 to 2019.

\section{Suggestions}

The company should reduce the cost of sales so as to achieve increased gross profit margin. The company needs to reduce expenses so as to achieve higher profits. The company should increase its operating income by putting in place, mechanisms that could help to compete in the market. The company should focus more to manage its administrative expenses and should pay more attention towards marketing. The company should review its human resources policy towards evaluating the performance of its employees.

The company should manage to pay off its debts to win the confidence of lenders/suppliers in the future. The company should look for alternative for the raw materials such as buying wheat from the local farmers. The company should work on finding ways and means to achieve good profits so as to satisfy the shareholders.

\section{Conclusion}

Salalah Mills Company has a good position in the local market, through maintaining $40 \%$ of the market share during the past five years. However, the presence of huge competition from local companies and the entry of foreign companies in the local market has affected its share. Therefore, the company must work to introduce new strategies to market its products locally, and expand its activities in the foreign markets. The company 
should also work on to develop a business strategy that helps to reduce direct and indirect costs and achieve higher profits.

\section{References}

1. Bartoloni, E., \& Baussola, M. (2014). Financial performance in manufacturing firms: a comparison between parametric and non-parametric approaches. Business Economics, 49(1), 32-45. https://doi.org/10.1057/be.2013.31

2. Behn, B. K., \& Riley Jr, R. A. (1999). Using nonfinancial information to predict financial performance: The case of the US airline industry. Journal of Accounting, Auditing \& Finance, 14(1), 29-56. https://doi.org/10.1177/0148558X9901400102

3. Capkun, V., Hameri, A. P., \& Weiss, L. A. (2009). On the relationship between inventory and financial performance in manufacturing companies. International Journal of Operations \& Production Management. 29(8). 789-806. https://doi.org/10.1108/01443570910977698

4. Duarte, A. L. D. C. M., Brito, L. A. L., Di Serio, L. C., \& Martins, G. S. (2011). Operational practices and financial performance: an empirical analysis of Brazilian manufacturing companies. BAR-Brazilian Administration Review, 8(4), 395-411. http://dx.doi.org/10.1590/s1807-76922011000400004

5. Efuntade, A. O., \& Akinola, A. O. (2020). Firm characteristics and financial performance in quoted manufacturing companies in Nigeria. International Journal of Business and Finance Management Research. 7. 25-32. http://doi.org/10.33500/ijbfmr.2020.08.004

6. Filer, R. K., \& Golbe, D. L. (2003). Debt, operating margin, and investment in workplace safety. The Journal of Industrial Economics, 51(3), 359-381.

7. Gamayuni, R. R. (2015). The Effect of Intangible Asset, financial performance, and financial policies on the firm value. International Journal of scientific and technology research,4(1), 202-212. http://www.ijstr.org/final-print/jan2015/The-Effect-Of-Intangible-Asset-Financial-Performance-AndFinancial-Policies-On-The-Firm-Value.pdf

8. Gatsi, J. G., Gadzo, S. G., \& Kportorgbi, H. K. (2013). The Effect of Corporate Income Tax on Financial performance of listed manufacturing firms in Ghana. Research Journal of Finance and Accounting, 4(15), 118-124.

9. Gazzola, P., \& Amelio, S. (2014). Is total comprehensive income or net income better for the evaluation of companies' financial performance? Central European Review of Economic. 17 (17) 39-51. https://doi.org/10.7327/cerei.2014.03.04

10. Harb, A. S. M. (2019). The Impact of Profitability and Financial Performance on Improving Productive Efficiency in Jordanian Industrial Companies. Academy of Strategic Management Journal, 18(5), 1-13. http://dx.doi.org/10.1590/s1807-76922011000400004

11. Kangari, R., Farid, F., \& Elgharib, H. M. (1992). Financial Performance Analysis for the Construction industry. Journal of Construction Engineering and Management, 118(2), 349-361. https://doi.org/10.1061/(ASCE)0733-9364(1992)118:2(349)

12. Kaplan R.S. (1983) Measuring manufacturing performance: a new challenge for managerial accounting research. In: Emmanuel C., Otley D., Merchant K. (eds) Readings in Accounting for Management Control. Springer, Boston, MA. https://doi.org/10.1007/978-1-4899-7138-8_14

13. Khan, F.R. (2019). Financial Statements for Entrepreneurs, GIAP Journals: India.

14. Khoja, L., Chipulu, M., \& Jayasekera, R. (2016). Analyzing corporate insolvency in the Gulf Cooperation Council using logistic regression and multidimensional scaling. Review of Quantitative Finance and Accounting, 46(3), 483-518. https://doi.org/10.1007/s11156-014-0476-y

15. Nariswari, T. N., \& Nugraha, N. M. (2020). Profit Growth: Impact of Net Profit Margin, Gross Profit Margin and Total Assests Turnover. International Journal of Finance \& Banking Studies (21474486), 9(4), 87-96. https://doi.org/10.20525/ijfbs.v9i4.937

16. Padma, D., \& Prabhakaran, M. K. (2019). Financial Performance of Selected Indian Food Products Industry During Post-Reform Period. International Journal of Research and Analytical Reviews, 6(2), 788-790.

17. Sahore, N., \& Verma, A. (2017). Corporate Disclosures and Financial Performance of Selected Indian Manufacturing and Non-Manufacturing Companies. Accounting and Finance Research, 6(1).

18. Suardi, I., \& Noor, K. D. (2015). The Impact of Capital Structure on Financial Performance of the Listed Agriculture Companies in Indonesia. Global Journal of Business and Social Science Review, 3(1), 9-17.

19. Williams, Revlon Orlando (2020), Corporate Social Responsibility and Financial Performance of U.S. Manufacturing and Service Small- and Medium-Sized Enterprises. Walden Dissertations and Doctoral Studies.

8592. https://scholarworks.waldenu.edu/dissertations/8592 
20. Yalcin, N., Bayrakdaroglu, A., \& Kahraman, C. (2012). Application of Fuzzy multi-criteria DecisionMaking methods for financial performance evaluation of Turkish manufacturing industries. Expert systems with applications, 39(1), 350-364. https://doi.org/10.1016/j.eswa.2011.07.024

21. Zahra, S. A., \& Das, S. R. (1993). Innovation strategy and financial performance in manufacturing companies: An empirical study. Production and operations management,2(1), 15-37. https://doi.org/10.1111/j.1937-5956.1993.tb00036.x

Copyright: () 2021 by the authors. Licensee Global Scientific Publications, Oman.

This work is licensed under a Creative Commons Attribution-ShareAlike 4.0 International License.

This is an open-access journal and the articles published in this journal are distributed under the terms of CC-BY-SA. 